\title{
Lost Alternatives to Council Housing? An examination of Stirling's alternative
} housing initiatives, c. 1906-1939.

\author{
James J. Smyth \& Douglas S. Robertson, University of Stirling.
}

\section{Introduction}

It is almost a century since the beginning of the great 'social experiment' that was council housing. ${ }^{1}$ Born out of a recognition of the poor quality of most housing for the working classes and the attendant health and mortality issues associated with overcrowding and poor sanitation and fuelled by the war-time promise of 'homes fit for heroes to live in' the agency chosen to deliver that promise was local government; councils constructing houses for rent backed by central state subsidy. In post-World War One (WW1) Scotland council housing almost immediately became the major provider of new houses, surpassing the number of new private builds as early as 1921 and thereafter out-performing the private sector every year (with the temporary exceptions of 1924 and 1925) until 1978 when the balance shifted back to the private sector which has maintained its dominance ever since. ${ }^{2}$ While the move to private build predates the Thatcherite 'privatisation' of selling off council houses to sitting tenants, that policy clearly reinforced the trend ${ }^{3}$ whereas in the 1970 s more than half of all homes were rented from a council, by 2011 the social rented sector provided just 24 per cent of homes with councils responsible for less than 13 per cent. Over the same period the proportion of owner-occupied homes doubled to over 60 per cent. ${ }^{4}$

Given that in the early years of the twentieth century the most common form of tenure was overwhelmingly private rented for both the working and middle classes (a category that now accounts for under fourteen per cent) it is clear that housing provision in Scotland has

\footnotetext{
${ }^{1}$ A. Ravetz, Council Housing and Culture: the History of a Social Experiment (London, 2001).

${ }^{2}$ National Statistics, Housing Statistics for Scotland 2015: Key Trends Summary (The Scottish Government), p7. Available at www.gov.scot/Resource/0048/00485857.pdf, accessed 17 November, 2015.

${ }^{3}$ R. Rodger (ed.), Scottish Housing in the Twentieth Century (Leicester, 1989), p. 2.

${ }^{4}$ The Accounts Commission, Housing in Scotland (Prepared by Audit Scotland, July 2013), pp. 9-10. Available at www.audit-scotland.gov.uk/docs/local/2013/nr_130711_housing_overview.pdf, accessed 17 November 2015.
} 
undergone major and dramatic shifts. ${ }^{5}$ And yet, one hundred years on housing remains in a state of near if not actual crisis. A report prepared by Audit Scotland in 2013 identified more than 34,000 homeless households and stated bluntly, 'The supply of housing is not meeting current levels of need.' It estimated that 'it could be more than 20 years before there are enough new homes to meet the projected increase in households in any one year. ${ }^{6}$

It is from within this context of a century of dramatic change and experimentation and yet a permanent housing problem that we intend to examine possible alternatives that may have been utilised immediately prior to and during the first wave of council house building. The point is not to argue that council housing was inherently flawed or that alternative provisions necessarily would have been better, but to get a sense of what other approaches were being considered to deal with Scotland's housing problem and why they were unable to compete with the Leviathan that became council housing. The Burgh of Stirling has been chosen because of our recent work on neighbourhood and identity within that city and because, as a classic 'independent' run council throughout the period of study with a limited Labour presence, it might have been assumed to have been less enthusiastic about building council houses and more amenable to exploring alternative solutions. ${ }^{7}$

Our interest in this topic has been stimulated by the recognition of other 'visions' of working class housing that existed in Stirling during this period. The first can be identified as socialist and based on what might be termed 'collective self-help'. This was the Homesteads experiment immediately prior to WW1 which successfully built a small number of houses with adjacent land on which the occupants grew food for themselves. The movers behind this

\footnotetext{
${ }^{5}$ Before 1914 fully 90 per cent of homes in Scotland were rented from private landlords. D. McCrone \& B. Elliot, 'The decline of landlordism: property rights and relationships in Edinburgh', in Rodger (ed.), Scottish Housing, p. 214. The instability of the current housing market is indicated by the fact that while a fraction of what it was a century ago the private rented sector has seen its share double from a low of seven per cent over the last decade. Scottish Government, Financial Memorandum prepared to accompany the Private Housing (Tenancies) (Scotland) Bill (SP Bill 79) as introduced in the Scottish Parliament on 7 October 2015. Edinburgh: Scottish Parliament. (2015) Available at www.scottishparliament.uk, accessed 9 December 2015.

${ }^{6}$ Housing in Scotland, p. 7.

${ }^{7}$ D. Robertson, J.J. Smyth \& I. McIntosh, Neighbourhood Identity: effects of time, location and social class, (Joseph Rowntree Foundation, York, 2008) www.jrf.org.uk/report/neighbourhood-identity-effects-timelocation-and-social-class; J.J. Smyth \& D. Robertson, 'Local Elites and Social Control: building council houses in Stirling between the wars', Urban History 40, 2, (2013) pp. 336-54; D. Robertson, I. McIntosh \& J.J. Smyth, 'Neighbourhood Identity: The Path Dependency of Class and Place', Housing, Theory and Society, 27, 3, (2010), pp. 258-273; D. Robertson \& J.J. Smyth, 'Tackling squalor: Housing's contribution to the welfare state', Social Policy Review, 21 (2009), pp. 87-108.; J.J. Smyth, D. Robertson \& I. McIntosh, 'The Raploch: A History, people's perceptions and the likely future of a problem housing estate', Architectural Heritage, XIX (2008), pp. 83-97.
} 
were mainly local members of the Independent Labour Party (ILP), the political force which perhaps did most to publicise and politicise the issue of working class housing prior to and during the War. ${ }^{8}$ The second experiment was a continuation of nineteenth century 'improvement'. This was a limited project by the Town Council, devised just before 1914, of demolition and widening a single street in the old town which sought to encourage private companies to build replacement tenements. Regarded at the time as almost wildly ambitious by the Council it was postponed due to the War and became a contested and limited effort thereafter. The third undertaking could be termed 'conservative' or 'free market philanthropy'. This was the Thistle Trust which, supported by local elites and with an outlook similar in many respects to the National Trust, sought to preserve the medieval dwellings huddled around Stirling Castle. This was widely recognised as a slum area that was ripe for demolition and whose tenants should be transferred to new council houses. The Thistle Trust, however, argued that with renovation and alteration these old houses could continue to function as homes and maintain the unique historic integrity of the old town.

\section{The Homesteads}

As a Royal Burgh with its strategically important Castle, Stirling enjoyed the benefits of court patronage only to suffer when the House of Stewart relocated to London in 1603. Largely moribund in the eighteenth century, Stirling enjoyed more rapid growth during the nineteenth century thanks to the coming of the railway and the development of mining and textiles in neighbouring villages. The burgh itself, however, remained largely reliant upon its traditional role as a market town servicing a productive and wealthy farming hinterland with a growing population of middle class commuters and retirees. ${ }^{9}$ As such Stirling, generally speaking, enjoyed better housing conditions than the rest of urban Scotland. For instance in 1908 the proportion of the Scottish population living more than two persons to a room was 46 per cent, with the figure for the larger burghs being 50 per cent. While Falkirk, Stirlingshire's other major urban centre, had a figure of 55 per cent, Stirling had, in contrast, only 35 per cent. ${ }^{10}$ Yet, Stirling still had its own housing problem. This was particularly concentrated on the ancient houses huddled around the Castle otherwise known as the 'tap o' toun'. The population density and decrepit state of the buildings there gave Stirling in 1908 a higher

\footnotetext{
${ }^{8}$ J.J. Smyth, Labour in Glasgow 1986-1936: Socialism, Suffrage Sectarianism (East Linton, 2000); J. Melling, Rent Strikes: People's Struggle for Housing in West Scotland 1890-1916 (Edinburgh, 1983).

${ }^{9}$ Robertson et al, Neighbourhood Identity, pp. 10-12.

${ }^{10}$ PP1908 [Cd 4016], Registrar General for Scotland, 'Return Showing the Housing Conditions of the Population of Scotland', pp. 6, 9 .
} 
mortality rate (19.5) than Falkirk (15.0) or even Glasgow (18.8). ${ }^{11}$ It was in response to such conditions, allied to a more general concern about rural depopulation that promoted the communal experiment which became known as the Homesteads. ${ }^{12}$

As was the case in Glasgow and elsewhere in Scotland the ILP agenda was increasingly focussed on housing in the years leading up to WW1. While housing and anti-landlordism had always been highly political issues in national and municipal politics, it was only in the years prior to 1914 that Labour began to find its own distinct voice by calling for the public provision of houses for the respectable working class, a position which presented a sharp opposition to the Liberal reliance upon the free market. ${ }^{13}$ The Stirling ILP was established in November 1906 and housing almost immediately became a major element of its local propaganda work. The interest of the membership was both general, calling for large-scale municipal house building and personal, keen to explore co-operative ways of living and working; three members of the original branch committee plus at least one more party member became original residents of the Homesteads. ${ }^{14}$ Typical of many socialists at the time, the Stirling membership was heavily influenced by the recent Garden City movement and the Arts and Crafts approach to life and work most famously articulated by William Morris.

The major figure in the Homesteads was Robert Maclaurin, an industrial chemist by occupation, who was also an active member of the Scottish Guild of Handicraft, established in Glasgow in 1900 as an 'Association of Art, Furniture and Metal Workers' by, among others, Roland Muirhead the well-known socialist and home rule activist. ${ }^{15}$ The Guild was registered as a Provident and Friendly Society and operated as a Labour Co-partnership, as the Homesteads would be. It took premises in the centre of Glasgow to showcase the work of members and organised exhibitions, including one on housing which was to provide the eventual design of the houses built for the Homesteads. In 1906 the Guild transferred its base

\footnotetext{
${ }^{11}$ P. Aitken, C. Cunningham \& B. McCutcheon, The Homesteads: Stirling's Garden Suburb (Stirling, 1984) p. 10 .

12 This is the best known of our three 'alternatives' having been the subject of a local study in the 1980s. Aitken et al, The Homesteads; also C.P. Aitken, 'Small Holdings and the Garden city Ideal: A Stirling Example, The Local Historian 17, 6 (1986), pp. 31-8.

${ }^{13}$ Smyth, Labour in Glasgow, pp. 65-9.

${ }^{14}$ Aitken et al, The Homesteads, p. 14.

${ }_{15}$ Aitken et al, The Homesteads p. 38. Maclaurin was married to Muirhead's sister Florence. In his twenties Muirhead, whose family claimed Chartist connections, had lived for a period in an Owenite community in Washington, USA. See H. Corr, 'Muirhead, Roland Eugene', in W. Knox, Scottish Labour Leaders 1918-1939: A Biographical Dictionary (Edinburgh, 1984) pp. 217-21.
} 
to Stirling which appears to have been directly related to Maclaurin's own move to the town. Although it is clear that the Guild was in serious difficulties by the time of the War, many of the furniture and fittings of the Homestead houses were made by Guild members. This must be seen not as mere affectation but as a genuine effort to live up to William Morris's 'golden rule': 'have nothing in your house that you do not know to be useful, or believe to be beautiful.' 16

While the Stirling ILP called for workers' housing to be built by the town council, along similar lines to the $£ 8$ cottages scheme popularised by John Wheatley and the Glasgow ILP, it is clear that this small group were also thinking about a new, co-operative scheme of their own. This ambition was certainly encouraged by moves for land reform within the new Liberal administration. As Sir Henry Campbell Bannerman, MP for Stirling and soon to be Prime Minister, put it during the general election campaign of 1905/06, 'We wish to make the land less of a pleasure ground for the rich and more of a treasure house for the nation., ${ }^{17}$ Legislation to promote small holdings was prepared for England and Scotland, with the former was passing quickly and smoothly in spite of its ambition to transform the face of English agriculture and the land system. ${ }^{18}$ In contrast the plans for Scotland faced fierce opposition from landlords. ${ }^{19}$

The main problem was that, unlike in England where local authorities were empowered to compulsorily purchase land, the proposed Scottish legislation was based on the existing situation in the crofting counties where holdings were created on privately owned land. The importation of this highland practice of 'dual ownership' to the lowland counties fuelled the rage of big landlords and their supporters. The Scotsman fulminated against repeating the 'Irish policy' and saw the Bill as an existential threat to the social order, 'dual ownership is

\footnotetext{
${ }^{16}$ This was stated by Morris in his 1880 lecture 'The Beauty of Life', quoted in E.P. Thompson, William Morris: Romantic to Revolutionary (London, 1955) p. 754. For the, artistic, moral and political imperatives behind such thinking with particular reference to housing reform see chapters four and five of Ravetz, Council Housing, 'The Utopian Roots of Council Housing' and 'The Artistic Inspiration of Council Housing', pp. 4166.

${ }^{17}$ Quoted in L. Leneman, Fit for Heroes? Land Settlement in Scotland after World War 1 (Aberdeen, 1989) p. 5. Leneman states that the words were uttered during Campbell-Bannerman's first speech in the new parliament, but Ewen Cameron correctly identifies the occasion as a speech made in December 1905. Ewen A. Cameron, Land for the People? The British Government and the Scottish Highlands, c. 1880-1925 (East Linton, 1996), p. 124.

${ }^{18}$ For detail on the Smallholdings and Allotments Act, 1907 and its 'failure' see Ian Packer, Lloyd George, Liberalism and the Land: The Land Issue and Party Politics in England, 1906-1914 (Woodbridge, 2001) pp. 38 - 48. See also Paul Readman, Land and Nation in England: Patriotism, National Identity and the Politics of Land, 1880-1914 (Woodbridge, 2008) p. 20, who gives a more positive account of the impact of the Liberal legislation while recognising it did not have the transformative effect many hoped it would have.

${ }^{19}$ Leneman, Fit for Heroes?, pp. 5-8.
} 
the first cousin to socialism' ${ }^{20}$ Opposition in the Lords meant the Scottish legislation was not passed until 1911. The full complexity of the debate over The Small Landholders (Scotland) Bill is detailed in Cameron, Land for the People, pp. 124-43, who stresses the inherent weaknesses of the Bill, divisions over its recommendations within the Liberal Party, and exploitation of the land issue for Scottish Liberalism's electoral advantage, rather than placing all the blame solely on a recalcitrant Tory House of Lords. ${ }^{21}$

Hostility to socialism and the perceived socialist project of the Homesteads was not confined to Tories. Local Liberal opinion in Stirling was set strongly against any proposals for municipal housing and tended to denigrate the Homestead experiment as a definitely socialist project. In spite of the fact those behind the project were (mostly) socialists this was a claim they felt they had to deny. In the same edition of the Scotsman quoted above there was a letter from Claude Wilson, responding to an earlier criticism of the Stirling scheme pointing out the high infant mortality in the town and expressly stating 'It is not a Socialist scheme.' 22 Similar claims and counter-claims were made in the Stirling press, particularly after an advert for the Small Holdings was placed in the Glasgow socialist weekly, Forward in July 1910. ${ }^{23}$ This advert was reproduced in the Stirling Observer the following week to which Wilson then replied pointing out that he was a supporter of the Liberal land policy of encouraging small holdings, which, he implied, the Observer (a Liberal organ) appeared to be in opposition to, and stressing that 'at no time has an intending applicant been interrogated regarding his politics. ${ }^{24}$

It is clear that a degree of shadow boxing was going on here. Local opposition was fuelled partly by a fear of encroachment on the public land around the Castle and partly by a more general antipathy towards socialism. The Stirling ILP was calling for the council to build houses on publicly-owned land, which was anathema to the local establishment. What allowed the Homesteads to be established prior to the Scottish Act of 1911 was that the land to be used was Crown land which allowed the Government to promote the scheme using existing legislation; neither Burgh land nor privately owned land was involved. In 1907 local authorities were reminded of their existing powers under the 1892 Small Holdings Act and

\footnotetext{
${ }^{20}$ The Scotsman, 24 October 1907.

${ }^{21}$ Cameron, Land for the People?, pp. 124-43.

${ }^{22}$ The Scotsman, 24 October 1907, James Claude Wilson was secretary of both the ILP and of Stirling Homesteads Ltd and one of the original homesteaders.

${ }^{23}$ Forward, 9 July 1910.

${ }^{24}$ Stirling Observer 23, 30 November.
} 
encouraged to advertise support for applications. It was from this process that the Homesteads emerged with a proposal for a co-operative venture of agricultural production involving ten families. After their initial site was rejected the Homesteads were established on 50 odd acres near to but not directly in front of the Castle. Establishing themselves as a public utility society under the Industrial and Provident Societies Act 1893, as the Scottish Guild of Handicraft was, then allowed them to utilise the Housing Town Planning Act 1909, the terms of which allowed such societies to borrow up to two thirds of the cost of the intended project. The actual cost of building the ten houses and their attached holdings and ancillary services came to $£ 3,555$ and in early summer 1910 the first homesteaders entered their new homes. ${ }^{25}$

As the Homesteads became a reality so gradually the sneering of the local press abated and a more generous attitude emerged. For instance in August 1910 one local account seemed most pleased that all the holdings were not yet let and that the houses were lacking their promised 'picturesqueness'. Admitting that the families claimed to be 'more than satisfied' with their new situation, it concluded that 'their experience will carry more weight after they have experienced a good old-fashioned winter. ${ }^{26}$ The following summer, however, a very different perspective was printed in another paper. Here now were productive and 'pretty gardens', indeed a 'model village'. The piece concluded, 'All success to Stirling Homestead and may there be many more of a similar nature introduced in many parts of Scotland, and may they assume ample dimensions and foster a contented and prosperous people. ${ }^{27}$

For all their claims that this was not a socialist colony, it is clear that the motivation of these pioneers was essentially socialist. Men like Wilson and Maclaurin were active socialists seeking improvement of Scotland's desperately poor housing while desiring a better life for themselves and their families. The Stirling Homesteads were unique in not just establishing individual small holdings but attempting a collective solution. They sought to be less reliant upon wage labour combined with greater fellowship with neighbours and friends. ${ }^{28}$ Their approach in the early 1900s was an eclectic, though common mix of Henry Georgite single tax, Liberal land reform, and ILP and Fabian socialism.

\footnotetext{
${ }^{25}$ Aitken et al, The Homesteads, pp. 14-26; for the detail on the passing of the Small Landholders (Scotland) Act 1911, see Leneman, Fit for Heroes?, pp. 5-19.

${ }^{26}$ Stirling Journal and Advertiser, 19 August 1910.

${ }^{27}$ Stirling Observer, 4 July 1911.

${ }^{28}$ S. Yeo, 'A New Life: The Religion of Socialism in Britain, 1883-1896', History Workshop Journal, 4 (1977), pp. 5-56.
} 
Maclaurin and his comrades were inspired by the early Garden City movement and the establishment of the first such development was at Letchworth in 1904. When Ebenezer Howard came to speak in Scotland in 1908 it was through the West of Scotland branch of the Garden Cities Association, the chief mover of which was Robert Maclaurin. Howard delivered a public lecture in Stirling on $7^{\text {th }}$ November and immediately after made a connection on how well he was received with the efforts of Baillie John Christie a generation earlier to establish a model village in Stirling. Born in Stirling in 1817 Christie became a Chartist as a young man while working in Birmingham, ideals he remained committed to on his return home. ${ }^{29}$ Other public events Maclaurin and his comrades promoted included a talk earlier in 1908 by the Fabian lecturer Montague Fordham on 'The Revival of Country Life', in which the speaker, while calling for public ownership of the land and heavier taxation on the rich said it should not be a return to agriculture 'pure and simple' but a new form of life including mechanics, artisans and tradesmen. ${ }^{30}$

How attractive or even possible such a life would have been to the working class of lowland Scotland is a moot point. In his advert in Forward Claude Wilson admitted that there was not much demand within Stirling and hoped that the publicity would prompt responses from those "eagerly demanding "back to the land"" ${ }^{31}$ Given that they were only looking to fill ten holdings would suggest the capital needed was beyond what most workers could afford, particularly given that historically Scots paid less for housing than did English tenants and that an industrial base highly vulnerable to the vagaries of the export market and the trade cycle made regular periods of unemployment and under employment a common life event. ${ }^{32}$ While the Homesteaders argued their case in terms of generally poor housing conditions it is clear that they were not themselves escaping the slums of the 'tap o' toun'. ${ }^{33}$

So far as we can generalise about such a small group, they can be categorised as lower middle class and skilled working class. The Census of 1911 reveals nine households in the Homesteads. Of the eight male heads of household present only one was born in Stirling, though one other was born nearby in Clackmannanshire. The others were all born in the central belt, though two had English wives: Edinburgh (2); Glasgow; Haddington;

\footnotetext{
${ }^{29}$ Aitken et al, The Homesteads, pp. 12-13. The Edinburgh branch of the Garden Cities Association actually built six cottages at Bannockburn in Stirling in 1908.

${ }^{30}$ Stirling Observer, 7 March 1908

${ }^{31}$ Forward, 9 July 1910; Aitken et al, The Homesteads, p. 27.

${ }^{32}$ R. Rodger, 'Employment, Wages and Poverty in the Scottish Cities 1841-1914', in G. Gordon, (ed.),

Perspectives of the Scottish City (Aberdeen, 1985) pp. 25-63.

${ }^{33}$ Aitken, 'Small-holdings', pp. 35-7.
} 
Rutherglen; Dunlop (Ayrshire); with the single female head born in Lochwinnoch

(Renfrewshire). The occupations of the male heads were: Engineer (fireclay); Brass Finisher; Compositor; Tailor; Printer's Reader; Printer; Iron Moulder. ${ }^{34}$ To this list we need to add Maclaurin (absent on Census night) whom we know was an Industrial Chemist. Of the group one was self-employed and one was an employer, the others being 'workers'. The size and value of the houses varied with the one detached property (Maclaurin) having the highest rental of $£ 20$ per annum, six houses at $£ 15.50$, two valued at $£ 9$ and one at $£ 8.25 .{ }^{35}$

\section{St Mary's Wynd Improvement Scheme}

Stirling Council was not overtly hostile to the Homesteads but it was opposed to the ILP's proposal that the $£ 12,000$ allocated for a new Municipal building should be allocated to building houses with gardens for the working class on Burgh land as a means of easing the congestion in the 'tap o' toun'. This opposition was based partly on a political desire to keep housing in the private sphere and partly from self-interest; many of the slum landlords were prominent citizens of the Burgh, including the Lord Provost. ${ }^{36}$ Nonetheless, the Council was not oblivious to the town's slum problem. Its first efforts in the early 1900 s were largely punitive and intrusive: Stirling adopted the system of 'ticketed' houses pioneered by Glasgow a generation previously whereby strict limits were placed on the number of inhabitants in any house, a regulation enforced by night inspections and the threat of fines on the householder; and by the appointment of a Lady Health Visitor. ${ }^{37}$ In 1912, however, a more positive policy was adopted: the St Mary’s Wynd Improvement Scheme.

The plan was to compulsory purchase and then demolish a number of the worst tenements near the Castle. These were in the notorious St Mary's Wynd and adjacent Broad Street. New tenements would be built with the street being widened and a children's playground provided. ${ }^{38}$ The major protagonist was the Burgh's Medical Officer of Health, and the scheme received the support of the Local Government Board. ${ }^{39}$ The Council saw its role as providing a model for private enterprise rather than building itself. While it retained the right

\footnotetext{
${ }^{34}$ Census 1911 490/00 016/00 020 \& 021, Burgh of Stirling.

${ }^{35}$ Valuation Roll for the County of Stirling 1915-1916.

${ }^{36}$ Royal Commission on the Housing of the Industrial Population of Scotland, Rural and Urban, Evidence, 4 Vols. (Edinburgh, 1921), Vol. 1, 718-9; Smyth \& Robertson, 'Local Elites', p. 340.

${ }^{37}$ Aitken et al, The Homesteads, pp. 11-12. Glasgow introduced 'ticketing' via it City Improvement Act 1866, a power that was eventually made available to all towns by the Burgh Police Act 1903; J. Butt, 'Working Class Housing in Glasgow', in S.D. Chapman, The History of Working Class Housing (Newton Abbott, 1971) pp. 55-92.

${ }^{38}$ Stirling Observer, 1 December 1912.

${ }^{39}$ Stirling Council Archives, Royal Burgh of Stirling, HH/R, 10/33:1 'Extracts from the Notes of a Local Enquiry into Housing'; Stirling Journal and Advertiser, 16 October 1912.
} 
to build if it could find no-one else to take on the project it was confident that private builders would be keen as there would be no 'restrictions on the rents'. ${ }^{40}$ This plan, which would at the most have seen the construction of eighteen homes, can be seen as Stirling's response to the growing clamour for housing reform taking place in these years and being given concrete expression in the Royal Commission on the Housing of the Working Classes which was currently taking evidence. Interestingly the Commission did not visit Stirling and the Council did not give evidence to it, the only submission from the town coming from the Trades Council through its representative Robert Maclaurin and the Rev. Primrose of Erskine United Free Church. ${ }^{41}$ While both men repeated the ILP policy of calling on the Council to build new homes on new sites, the local press provided no coverage of their interviews by the Commission.

The Council's improvement scheme was opposed by the ILP and Trades Council partly because of the moral qualm of putting money in the pockets of slum landlords through compulsory purchase when there was much cheaper land available where new cottage style houses could be built, and partly because of the nature of the proposed new tenements. While most of the flats would have one room, a kitchen, scullery and indoor toilet, there would be some one room flats. The absolute prohibition of the one-roomed house had become a matter of faith for Scottish Labour and as one candidate put the matter in Stirling, 'there was no sense trying to get rid of one evil by setting up another in its place.' 42

Like many city improvement schemes, such as the earlier and much larger Glasgow and Edinburgh developments, Stirling's plans proved more difficult to realise than first assumed. ${ }^{43}$ There was no clamour from private builders to take the feu of the site and soon the war intervened. This was given by the Council as the reason for its apparent inactivity since getting the go ahead in late 1913. Given the new and more generous subsidy offered by the Housing and Town Planning Act (Scotland) 1919 Stirling now sought to have its scheme brought under that remit, arguing that the cost in interest of the original scheme was equivalent to a rate of $1 \frac{1 / 2}{2}$ pence in the pound, whereas under the new legislation the burden

\footnotetext{
40 Stirling Observer, 1 December 1912.

${ }^{41}$ RC Housing, Evidence, Vol. 1, 714-21; Vol. 2, 1483-5.

42 Stirling Journal and Advertiser, 6 November 1912. In his statement to the Royal Commission Maclaurin reiterated the Labour view that "no new houses should be built with public money containing less than two apartments, bathroom, with w.c. and scullery'. RC Housing, Evidence, Vol. 1, p. 714.

43 Butt, 'Working Class Housing'; P.J. Smith, 'Slum Clearance as an Instrument of Sanitary Reform: The Flawed Vision of Edinburgh's first Slum Clearance', Planning Perspectives, 9, 1 (1994) pp. 1-27.
} 
would be $4 / 5$ ths of a penny only. ${ }^{44}$ Unfortunately the Act explicitly stated that it would not consider any support for any site purchased prior to 12 January 1919. The Council came under outside pressure also from agencies which were opposed to its plans to demolish the existing tenements. His Majesty's Office of Works (HMOW) got involved due to its role as custodian of the Castle, a designated Royal Palace, as did the recently established (1908) Royal Commission on Ancient and Historical Monuments (RCAHMS). Both bodies wished to preserve the architectural and historical integrity of the whole area around the Castle and argued for the preservation of the existing buildings rather than their demolition. The heads of both, Lionel Earl at HMOW and Stirling Maxwell at RCAHMS, collaborated with the latter funding a survey to cost an alternative rehabilitation scheme. ${ }^{45}$

There was a degree of support for this within the Council, including the Town Clerk and the Burgh Surveyor, who recognised the historical importance and potential value to Stirling of retaining its medieval town centre. Unfortunately preservation was more costly than building new and neither HMOW nor RCAHMS had any remit or funds to spend on such a scheme, and the existing legislation only offered subsidies to new-build housing. Efforts to get the Scottish Board of Health to provide financial aid and direct appeals to the Scottish Secretary, Sir John Gilmour came to nothing, with Gilmour stating bluntly, 'I have no funds at my disposal. ${ }^{46}$ Not surprisingly the Council was unwilling to shoulder the burden on its own and effectively abandoned the renovation scheme in 1925. It then proceeded with its original improvement scheme and went ahead with demolition, much to the disgust of Earl and Maxwell. ${ }^{47}$

What to do with the 'tap o' toun' would remain an issue in Stirling till the 1950s and perhaps the improvement scheme, particularly the preservation alternative, might have provided a model for how best to make practical use of historical dwellings. By the end of the war, however, the political situation had changed utterly. The policy of central Government, as

\footnotetext{
${ }^{44}$ NRS, DD6/673, Housing Schemes - Policy, 1919 Representations on financing of Housing Scheme in St Mary's Wynd, Stirling, Letter to The Rt. Hon Robert Munro MP, Secretary for Scotland, Scottish Office, Whitehall, from Town Clerk: David B Morris, 25 November 1919.

${ }^{45}$ NRS, MW1/1184, 'St Mary's Wynd and Broad Street, Stirling, 1912-1926 Improvement Scheme', MW1/1184/00038 Internal memo from HM Office of Works noting 'strong local feeling in Stirling for preservation of old buildings', 8 May 1924.

${ }^{46}$ NRS, MW1/1184/00107, Letter from Sir John Gilmour to Lionel Earl, 22 June 1925; see also MW1/1184/00106, Letter from Earl to Gilmour, 28 May 1925.

${ }^{47}$ NRS, MW1/1184/00094, Letter from David B Morris, Town Clerk Stirling to Secretary Lionel Earl, HM Office of Works London, $16^{\text {th }}$ December, 1924; MW1/1184/00116 HMOW Minute sheet note by Earl, $8^{\text {th }}$ April, 1925.
} 
articulated by the Addison Act 1919, forced local councils, willingly or not, to embrace council housing as the only effective solution to the housing crisis. Promoted through subsidy many of the first council houses would be a version of the cottage style home promoted by the ILP prior to the War. And when the effort at clearing the slums from the town centre was made under later legislation, the new houses would be built on the green fields around the Castle owned by the Burgh, as Robert Maclaurin and his colleagues had proposed.

\section{The Thistle Trust}

With a few minor exceptions such as the Broad Street tenement, getting round to slum clearance was not an immediate priority. For all the earlier concern with the poor the first Council houses were effectively built for the 'respectable' working class and indeed the lower middle class. Apart from anything else only they could afford the relatively high rents. It was not until the end of the 1920s and into the 1930s that provision was made to re-house the inhabitants of the 'tap o' toun' in the slum clearance estate of Raploch. ${ }^{48}$ In the meantime there continued to be a concern among interested and elite groups in preserving the town centre and providing affordable homes for the poorer working class. This was, in turn, linked to a general hostility to state provision of housing and a recognition that the slum dwellers were not being provided for. In political terms this tended to be expressed by arguing that the new council tenants could afford to rent privately and so were in fact being subsidised by the poorer rate payers. ${ }^{49}$

In 1927 the Thistle Trust was established in Stirling with the apparent intention of taking over and implementing the rehabilitation plans of RCAHMS and HMOW. The Trust shared their views that the historic buildings should be retained and renovated rather than demolished. It is likely the Trust was influenced by the ideas of Patrick Geddes on the need for 'conservative surgery' in the urban environment and its members would have been aware of the moves to create the National Trust of Scotland (NTS) which was achieved in 1930 largely through the efforts of Stirling Maxwell. From its beginning the NTS was committed to preserving the small houses of Scotland's burghs and was, like the Thistle Trust, hostile to the new 'socialist' housing schemes being built by the municipal authorities. ${ }^{50}$ By the mid1920s the Town Council had become the owner of a number of other tenements in the old

\footnotetext{
${ }^{48}$ Smyth \& Robertson, 'Local Elites', pp. 347-9.

${ }^{49}$ Robertson \& Smyth, 'Tackling Squalor'; Stirling Journal \& Advertiser 19 February 1920, 14 May 1931.

${ }^{50}$ D. Waters \& M. Glendinning, Little Houses: The National Trust for Scotland's Improvement Scheme for Small Historic Homes (Edinburgh, 2006) pp. 12-22.
} 
centre but, as detailed above, was hamstrung by the lack of subsidy for renovation and thus was unable to do much other than plan for their eventual demolition. In the same year it stated that it had at least 500 families on its waiting list for houses, and that the area was suffering an outbreak of diphtheria in properties that had been condemned twenty years previously. ${ }^{51}$ Since 217 houses had been declared uninhabitable in the Burgh in 1920 but the figure in 1927 had risen to 397, there was clearly little or no progress being made in tackling the problems of the 'tap o' toun'. ${ }^{52}$ It would appear that the Trust and the Council worked closely together from the beginning in a 'spirit of co-operation' that, as one (male) member of the Trust put it, 'dispelled any idea that might have been in the mind of the Local Authority that the Trust was another collection of old women of both sexes. ${ }^{53}$

The Trust's establishment credentials were impeccable; the first Chair was Lady SteelMaitland married to Sir Arthur Steel-Maitland, Minister of Labour under Baldwin's Conservative administration from 1924-1929. ${ }^{54}$ The Lord Provost subsequently took over as Chair while Lady Steel-Maitland became a very active Honorary President and a panoply of significant figures could be called upon to support its efforts, such as the novelist and MP John Buchan. Just like the Homesteads the Trust established itself as a Public Utility Society and sought to raise funds through share capital from, among others, the tenants, and donations from the great and the good. By late 1927 / early 1928 the Trust had bought ten properties in St Mary's Wynd (the site of the Council's original improvement plan) and four in St John's Street. ${ }^{55}$ The commitment of the Trust to the tenants was that their homes would be reconditioned without them being dispossessed.

The houses purchased by the Trust were exceptionally decrepit; at 74 St Mary's Wynd eight families shared one sink. After refurbishment the houses would remain small, indeed very small, but they would have internal services such as kitchen sinks and toilets. It is a reflection on how poor housing conditions were and how scarce good housing was that the Honorary Secretary, Margaret Murray, could report to Lady Maitland that after a meeting Labour

\footnotetext{
${ }^{51}$ Stirling Journal \& Advertiser, 20 October 1927.

${ }^{52}$ Stirling Journal \& Advertiser, 20 May 1920, 6 October 1927.

53 Scotsman, 26 March 1938.

${ }^{54}$ See NRS, GD 193/193/T, Lady Steel Maitland Papers, Thistle Trust 1935. Arthur Steel-Maitland was the first Conservative Party chairman, was a convinced tariff reformer, and had a particular interest in social policy, as well as being an active member of the Church of Scotland, serving as a Kirk elder in the Parish of St Ninian's in Stirling. See E. H. H. Green, 'Maitland, Sir Arthur Herbert Drummond Ramsay-Steel- , first baronet (18761935)’, Oxford Dictionary of National Biography, Oxford University Press, 2004; online edn, May 2009 [http://www.oxforddnb.com.ezproxy.stir.ac.uk/view/article/36263, accessed 6 April 2016] 55 Stirling Valuation Roll, 1928-1929.
} 
councillors approached her saying that "many of their members would be willing to contribute' to the system of buying shares by instalments. ${ }^{56}$ By early 1930 the Trust had raised a total of $£ 4,230$ comprising $£ 1,791$ in shares, $£ 1,660$ in Loan stock, and $£ 779$ in donations. ${ }^{57}$ In order to promote and extend the project more and more reliance was going to be placed on raising donations; the previous summer the Trust had launched an appeal for $£ 20,000 .^{58}$

The means by which this was to be done was through tapping into the largess of wealthy supporters. For instance in June 1933 a Grand Fete was held in in the grounds of the local Touch Estate under the patronage of the Countess of Mar and Lady Kay Muir of Blairdrummond. Music at the event was provided by the Argyll \& Sutherland Highlanders and 'many titled ladies acted as stallholders'. The keynote speech was made by Sir D.Y. Cameron, the King's painter in Scotland and one of the Trust's vice-presidents, who stressed the value of 'individual effort' and private enterprise. He contrasted what the Trust was attempting to do in preserving the beauty of the old houses, with the desire of 'public bodies' to destroy 'so they might make a wonderful report to Parliament.' In a coded but obvious reference to the new council slum clearance houses built 'by the river' he argued these were the 'new slums' which would be long gone while the 'old houses' having stood for hundreds of years 'might live for hundreds of years yet' thanks to the efforts of the Trust. ${ }^{59}$ The Fete raised $£ 460$ with an anonymous donor meeting the expenses of the event. At the same time it was reported that the maximum grant of $£ 100$ per house had been approved by Stirling Council. ${ }^{60}$

The Thistle Trust garnered a significant female input. Not only was Lady Steel-Maitland head of the Trust, she was also President of the Stirling Branch of the National Council of Women (NCW) and the Stirling Nursing Association, as well as being a lifelong member of St Ninian's Old Parish Church and Vice-President of the West Stirlingshire Unionist Association. Indeed it would appear that the whole idea of the Trust emerged out of the Stirling NCW. ${ }^{61}$ As a sort of establishment feminism the Trust consciously adopted the

\footnotetext{
${ }^{56}$ NRS GD193/193T, 'Letter to Lady Steel-Maitland from Margaret Murray, 27 November 1927'.

${ }^{57}$ NRS GD193/193/T, 'Minute of meeting, 10 January 1930'.

${ }^{58}$ Dundee Courier, 19 June 1929.

${ }^{59}$ The Scotsman, 8 June 1933.

${ }^{60}$ The Scotsman, 9 June 1933.

${ }^{61}$ The Scotsman, 26 March 1936. For an account of feminist political activity at this time which included housing as a major issue, see S. Innes, 'Constructing Women's Citizenship in the Interwar Period: the Edinburgh Women Citizen's Association', Women's History Review, 13, 4 (2204), pp. 621-47.
} 
'Octavia Hill system' of having a female manager on site to direct both the properties and the tenants. As Lady Kay Muir, President of the Stirling NCW put it to her fellow members in 1932, 'The workers of the Trust aimed at human reconditioning as well as house reconditioning. ${ }^{62}$ The manager appointed by the Trust was a Miss Curror, who was a Justice of the Peace also. In a talk given to the Falkirk Women's Association, Curror contrasted the absence of women property managers in Scotland with the large numbers employed by local authorities and housing trusts in England. In Scottish towns, she argued, the custom was to appoint an additional sanitary inspector, health visitor or nurse, the focus always being on 'bad houses'. Among the advantages of a women manager was that she could include the same work in her ordinary duties and that she dealt with both 'good and bad alike'. It was mainly women who were housekeepers and paid the rent and Curror claimed that schemes with women managers saw decreases in levels of rent arrears, as well as helping with rents, repairs, inspections, hearing complaints, visiting new tenants, etc. Their 'tact and understanding do much for the guidance of tenants. ${ }^{63}$ An annual gardening competition, to be judged by the great and the good, was instigated which, in 1933, saw several tenants disqualified for failing to grow the required minimum of four rows of potatoes. ${ }^{64}$

In March 1935 two more tenements in St Mary's Wynd were reconditioned by the Trust and opened by the Duchess of Montrose who paid tribute to the 'strong walls' of the original buildings. ${ }^{65}$ Thereafter, however, it seems to have run out of steam. The lack of records left by the Trust make it difficult to be absolutely certain but there is no evidence that the $£ 20,000$ fund aimed for in 1929 was ever realised. Without access to large-scale private donations there was a definite limit on what the Trust could achieve. Speaking in 1938 Lady Muir admitted that the 'Material achievement' of the Trust might be seen as 'somewhat limited' but it had, nonetheless 'proved to be a successful pioneer'. She then went on to point out the danger to 'individualism and liberty' by central State control, 'and over-readiness on the part of the people to be spoon-fed by the State from cradle to the tomb. ${ }^{66}$ And yet, the real

\footnotetext{
${ }^{62}$ The Scotsman, 26 Nov. 1932. For the supervisory and disciplinary function of male house factors and female nurse and sanitary inspectors, (the 'green ladies' in popular parlance), in inter-war Glasgow municipal housing schemes, see S. Damer, "'Engineers of the Human Machine": The Social Practice of Council Housing Management in Glasgow, 1895-1939', Urban Studies, 37, 11 (2000), pp. 2007-26.

${ }^{63}$ The Falkirk Herald, 2 November 1935.

${ }^{64}$ NRS GD193/193T, Minutes of management committee meeting of Thistle Property Trust Ltd, 4 August 1933.

65 The Scotsman, 27 March 1935.

${ }^{66}$ Scotsman, 26 March 1938. For an earlier, similar effort at preservation and philanthropy within a free market context see R.J. Morris, 'White Horse Close: Philanthropy, Scottish Historical Imagination and the Rebuilding of Edinburgh in the Later Nineteenth Century, Journal of Scottish Historical Studies, 33, 1 (2013) pp. 101-128.
} 
stumbling block for the Trust was its inability to access State subsidies. The Thistle Trust, at the instigation of Margaret Murray, had joined the National Federation of Housing Societies (NFH) when it was founded in January 1935 as the main vehicle for influencing Government policy; the hope being that subsidies could be extended to renovating existing properties. ${ }^{67}$

In Scotland whatever local or individual voices might oppose state provision in parliamentary terms there was little opposition to building council houses, even under the National Government in office from 1931. As Hutchison has put it, 'The adoption of an interventionist approach was central to the Unionist appeal in Scotland. ... [and] The most important issue developed by the Unionists to establish their social concern credentials was housing. ${ }^{68}$ The Scottish Office pursued a large-scale council housing policy under the National Liberal, Sir Godfrey Collins and even more so under his successor in 1936, the Conservative Walter Elliot. The aim, with a particular emphasis on slum clearance, was simply to get as many houses built as possible, and building new on fresh sites was cheaper than renovating the old. The Thistle Trust and its supporters found themselves up against what they saw as an in-built government hostility to renovation, an official view that regarded it as more or less impossible 'that an old house, once it is condemned, can be used again for housing purposes'. ${ }^{69}$ In spite of their 'practical experience' of 'intelligent modification' the Trust's approach seems to have been given lip service only. In 1937 Margaret Murray took Walter Elliot to task for saying that Housing Associations could receive subsidy through the Overcrowding Act 1935 though Scotland had only one such Association. Murray's point was that Scotland had in fact three housing associations yet only the Edinburgh Welfare Trust could secure the subsidy because it built new houses. The Thistle Trust and Better Homes of Perth specialised in the modernisation of existing stone buildings and were therefore unable to use the 1935 legislation and could only get assistance through the much less generous provisions of the Housing (Rural Workers) Act $1926 .{ }^{70}$

The following year the Trust alongside Stirling NCW and the National Federation of Housing Societies (NFHS) organised a major conference on Scotland's housing needs. This was the

\footnotetext{
Morris uses the term 'managed' or 'authoritarian philanthropy' to describe the activities of the Patrick Geddes founded Edinburgh Social Union and stresses the role played by elite women.

${ }^{67}$ NRS GD193/193T, Sheet of typed excerpts from correspondence with Mr Dandie re Housing Bill by Margaret Murray, January 1935. Though little is known of her it would appear from the limited records available that Murray was the driving force behind the Trust.

${ }^{68}$ I.G.C Hutchison, Scottish Politics in the Twentieth Century (Basingstoke, 2001), pp. 50-51.

${ }^{69}$ The Scotsman, 23 May 1936.

70 The Scotsman, 7 June 1937.
} 
venue in which Lady Muir made her attack on spoon-feeding by the state but her tone and message was increasingly at odds with actual policy. The main speaker was Sir William E. Whyte, one of the pioneers of town planning in Scotland, who laid out the extent of the problem. One in four working class homes (or 221,000 families) were overcrowded; 50,000 working class homes that had been declared unfit for human habitation were still occupied; one third of Scottish homes were without a separate w.c. and even more lacked a bath. Whyte calculated that 250,000 further homes were needed over the next ten years and made it clear that this could be achieved only if the subsidies available to local authorities for alleviating overcrowding were raised and made secure over the long term. Attending the conference with a watching brief from the Department of Health was one Archibald Stalker and his comments were hardly conducive to the ambitions of the Thistle Trust. The Trust had largely focussed on the needs of elderly and childless couples, recognising that their properties were hardly suitable for families. Stalker pointed out that no mention had been made of children at the conference when, after all, much of Scottish overcrowding was linked to numbers of children. And finally, 'He urged the Thistle Trust not to confine itself to architectural reconstruction, and to providing for small families. ${ }^{, 71}$

\section{Conclusion}

Presenting his 1924 Housing Act in Parliament and responding to the challenge of Neville Chamberlain that he was hostile to home ownership, John Wheatley stated, 'I own the house I live in and I make it a rule in my public life to try to bring to others the facilities and privileges that I have myself. ${ }^{72}$ So was the building of council housing inevitable after the Great War? This question is particularly relevant to Scotland, given the much greater, indeed dominant share of the housing stock the public-rented sector came to represent north of the border. Between 1919 and 1941 local authorities in Scotland were responsible for building 70 per cent of new houses, compared to a figure of just 28 per cent in England \& Wales. ${ }^{73}$ As we have seen, the socialist view pre-1914 was that the local authority should provide cottage style houses for working class families. This was so in Stirling as well as Glasgow where under the leadership of John Wheatley, the ILP argued that the Council use the surplus from the municipally owned and profitable tramways to build ' $£ 8$ Cottages'. In essence this was

\footnotetext{
${ }^{71}$ The Scotsman, 26 March 1938.

${ }^{72}$ Quoted in I.S. Wood, John Wheatley (Manchester, 1990), p. 133.

${ }^{73}$ R. Rodger \& H. Al-Qaddo, 'The Scottish Special Housing Association and the implementation of housing policy 1937-87', in Rodger (ed.), Scottish Housing, p. 185.
} 
the viewpoint that triumphed in the Royal Commission on Housing which made its report in 1917; the major difference being that Westminster 'should impose the obligation on the Local Authority' which would be supported by means of access to central government subsidies. ${ }^{74}$

With Addison's Housing Act 1919 in place the great 'social experiment' began. The very first council built homes in Stirling at Riverside corresponded very closely to the cottage ideal of both the ILP and the Garden City movement and were similar to the Homesteads. The social complexion of the tenants was also very similar to the skilled working class / lower middle class Homestead community, albeit on a much larger scale. This utopian period did not last long, however. Right-wing hostility to cosseting the working classes who were, in this view, simply not willing to pay more for a decent home, alongside retrenchment in the central government budget, saw a reduction in the subsidy in Chamberlain's Housing Act 1923. The famous Wheatley Act of the following year sought to return to the immediate postwar ambitions and did so by increasing the subsidy but also by reducing standards in order to increase the number of new-builds. ${ }^{75}$ It is, perhaps, from this point on that council housing has been seen by some historians as essentially a failed, if not doomed, experiment. I.S. Mclean has made the cryptic comment, 'John Wheatley's Housing Act of 1924 was a product of Red Clydeside, but so are Glasgow's awful council house ghettos. ${ }^{76}$ Yet Mclean appears to challenge his own assertion later in the same work, 'The solid brick terraces which march across the inner suburbs of every British city could not have been built without John Wheatley. They will remain while newer houses are abandoned, vandalised, or blown up after becoming unlettable. ${ }^{77}$ If council house 'ghettos' were created it was mostly due to the later slum clearance legislation which allowed much smaller, and even more poorly constructed houses to be built. It was these homes which the members of the Thistle Trust, and the MOH for Stirling, had described as the 'slums of the future'. ${ }^{78}$

Would the three alternatives examined here have offered a better or series of better options in housing the working class of Scotland? Stirling's own improvement scheme seems to have

\footnotetext{
${ }^{74}$ The Commission concluded, 'There is, in our view, only one alternative: the state itself, through local authorities, is alone in a position to assume responsibility.' At the same time the Tudor Walters Committee submitted its report covering England, Wales and Scotland, becoming 'the "Bible" of the new council housing.' Ravetz, Council Housing, p. 75.

75 Smyth \& Robertson, 'Local Elites’, p. 347; N. Morgan, “" $£ 8$ Cottages for Glasgow Citizens": Innovations in municipal house building in Glasgow in the inter-war years', in Rodger, Scottish Housing, p. 141. This was repeated by Harold MacMillan when he was housing minister in the 1950s. See Ravetz, Council Housing, p. 97.

${ }^{76}$ I.S. Mclean, The Legend of Red Clydeside (Edinburgh, 1983) p. 2.

${ }^{77}$ Mclean, Legend, p. 218.

${ }^{78}$ Smyth \& Robertson, 'Local Elites', p. 351; Stirling Journal \& Advertiser, 23 January 1936.
} 
been doomed almost before it began. Stuck in the nineteenth century mind set of what constituted 'improvement' it offered only a partial solution to the Burgh's housing problem; that of encouraging private builders onto municipally 'cleared' land. This had failed to work in Glasgow and similarly failed in Stirling. One gets the sense that the Council was relieved when the Trust stepped into the breach in 1927. Moreover, the wholly different context at the end of WW1 meant that housing provision would be considered as dealing in the thousands rather than a couple of dozen. Had the financial provisions of the various Housing Acts been sufficiently subtle to have allowed support for renovation alongside new-build then the fate of the improvement scheme and Stirling's historic town centre might have been very different. Perhaps the Geddes inspired 'conservative surgery' pursued through RCAHMS and the 'conservative philanthropy' of the Thistle Trust would not have been needed. Yet the Trust, for all is emphasis on individualism and personal independence ultimately failed because of the same hurdle; without access to state subsidy the Trust could not take on the number of old tenements it wanted to. Private philanthropy could not raise the necessary funds nor were the tenants of the 'tap o' toun' capable of subscribing to share capital. And even with all its establishment connections, the Trust could not change Government policy. ${ }^{79}$

The Homesteads is perhaps the most engaging of our three alternative paths with its almost Scandinavian combination of independence and mutuality. The Homesteaders, however, did not seek to remove themselves from society, they knew they could never be self-sufficient completely, and they were highly active in campaigning for better housing for all. The men and women behind this experiment were inspired to explore a different way of living and though contemporaries found it easy to mock their efforts they survived and those houses still remain today, though as part of the general private housing market in Stirling and no longer as a co-operative venture. However, it can hardly be argued that the Homesteaders were leading a flight of people looking for a way 'back to the land'. The fact that they had to advertise beyond Stirling for participants was recognition that there was no great demand

\footnotetext{
${ }^{79}$ Margaret Murray, the secretary of the Thistle Trust, clearly concluded that public subsidy was a necessity if old tenement buildings were to be modernised, hence her unsuccessful attempt to have the Housing (Scotland) Act, 1935 amended to allow for that. In their 1947 report, Modernising our Homes, the Scottish Housing Advisory Committee, came to the exact same conclusion, but it was not for a further twenty years that this change came into being under the Housing (Scotland) Act, 1968, which enacted the recommendations of another Scottish Housing Advisory Committee report, the 1967 Cullingworth Report, Scotland's Older Homes, which advocated such subsidies. A detailed examination of this issue is provided in; D. Robertson Scottish home improvement policy, 1945-75: Coming to terms with the tenement, Urban Studies, 29, 7, 1992, pp. 1115 -1136
} 
within the area. Moreover between 1919 and 1927 of the 2,331 new small holdings created in Scotland not a single one was in the County of Stirling. ${ }^{80}$

The scale of Scotland's housing problem and the demand for habitable houses were both enormous and it is difficult to see how any of our three 'alternatives' could have made a significant contribution to that need. Of the 344,209 new houses built in Scotland between 1919 and 1941, some 103,191 were built by private enterprise and 241,018 by local authorities including the Scottish Special Housing Association (SSHA) from 1937. ${ }^{81}$ In Stirling the Council built 2,121 houses between 1919 and 1938. The dominance of the public sector in the town can be gauged by the fact that of the 1,772 houses built between 1929 and 1939 only 115 were built by the private sector. ${ }^{82}$ It may be that such minority interventions as explored here should have been encouraged in order to provide a more nuanced and balanced physical and social structure, but for most Scots needing a family home in the early to midtwentieth century, council housing was the only option.

\footnotetext{
${ }^{80}$ Neither were any of the 1206 enlargements of existing holdings. Leneman, Fit for Heroes?, p. 38.

${ }^{81}$ Rodger \& Al-Qaddo, 'Scottish Special Housing', p. 185.

${ }^{82}$ Smyth \& Robertson, 'Local Elites', pp. 352-3; PP1943-44 [Cd. 6552], Department of Health for Scotland, Distribution of new houses in Scotland, Report by the Scottish Housing Advisory Committee, p. 43.
} 